\title{
Gluconobacter japonicus sp. nov., an acetic acid bacterium in the Alphaproteobacteria
}

\author{
Correspondence \\ Yuzo Yamada \\ yamada333@kch.biglobe.ne.jp
}

\author{
Taweesak Malimas, ${ }^{1}$ Pattaraporn Yukphan, ${ }^{1}$ Mai Takahashi, ${ }^{2}$ \\ Yuki Muramatsu, ${ }^{2}$ Mika Kaneyasu, ${ }^{2}$ Wanchern Potacharoen, ${ }^{1}$ \\ Somboon Tanasupawat, ${ }^{3}$ Yasuyoshi Nakagawa, ${ }^{2}$ Morakot Tanticharoen ${ }^{1}$ \\ and Yuzo Yamada ${ }^{1} \dagger$
${ }^{1}$ BIOTEC Culture Collection (BCC), National Center for Genetic Engineering and Biotechnology (BIOTEC), Pathumthani 12120, Thailand
${ }^{2}$ Biological Resource Center (NBRC), Department of Biotechnology, National Institute of Technology and Evaluation (NITE), Kisarazu 292-0818, Japan Bangkok 10330, Thailand \\ ${ }^{3}$ Department of Microbiology, Faculty of Pharmaceutical Sciences, Chulalongkorn University,
}

\begin{abstract}
Five strains, NBRC $3271^{\top}$, NBRC 3272, NBRC 3263, NBRC 3260 and NBRC 3269 were examined genetically, phylogenetically, phenotypically and chemotaxonomically. The DNA G + C contents of the five strains were 55.1-56.4 mol\%. The five strains had low levels of DNA-DNA hybridization of $13-51 \%$ to the type strains of Gluconobacter frateurii, Gluconobacter thailandicus, Gluconobacter oxydans, Gluconobacter cerinus, Gluconobacter albidus and Gluconobacter kondonii and formed a cluster that was separate from the type strains of the six Gluconobacter species given above in phylogenetic trees based on 16S rRNA gene and 16S$23 S$ rRNA gene internal transcribed spacer sequences. The five strains weakly produced dihydroxyacetone from glycerol, but not 2,5-diketo-D-gluconate or a water-soluble brown pigment from D-glucose and contained ubiquinone-10. The five strains were assigned as representing a novel species of the genus Gluconobacter, for which the name Gluconobacter japonicus sp. nov. is proposed. The type strain is NBRC $3271^{\top}\left(=\mathrm{BCC} 14458^{\top}=\right.$ strain $7^{\top}, \mathrm{K}$. Kondo). Cells of the type strain are motile by means of polar flagella and the DNA G+C content is $56.4 \mathrm{~mol} \%$.
\end{abstract}

Members of the genus Gluconobacter are characterized physiologically as not being able to oxidize acetate and lactate and chemotaxonomically by having ubiquinone- 10 (Q-10) as a major quinone (Asai, 1935; Asai et al., 1964; Yamada et al., 1969; Gosselé et al., 1983). The combination of the phenotypic and the chemotaxonomic characteristics has been used to classify a large number of isolated acetic acid bacteria as belonging to the genus Gluconobacter

†JICA Senior Overseas Volunteer, Japan International Cooperation Agency (JICA), Shibuya-ku, Tokyo 151-8558, Japan; Professor Emeritus, Shizuoka University, Shizuoka 422-8529, Japan.

Abbreviation: ITS, internal transcribed spacer.

The GenBank/EMBL/DDBJ accession numbers for the 16S rRNA gene sequences of strains NBRC $3271^{\top}$, NBRC 3260, NBRC 3263, NBRC 3272 and NBRC 3269 are AB253435, AB178400, AB253434, AB253436 and AB178408, respectively.

A table showing DNA-DNA hybridization values for strains NBRC $3271^{\top}$, NBRC 3260, NBRC 3263, NBRC 3272 and NBRC 3269 and the type strains of other species of Gluconobacter and Acetobacter aceti is available as supplementary material with the online version of this paper.
(Yamada et al., 1999; Tanaka et al., 1999; Huong et al., 2007).

At the time of writing, the genus Gluconobacter contained seven species with validly published names: G. oxydans (the type species), G. cerinus, G. frateurii, G. asaii, G. albidus, G. thailandicus and G. kondonii (De Ley, 1961; Skerman et al., 1980; Gosselé et al., 1983; Yamada \& Akita, 1984a, b; Mason \& Claus, 1989; Yukphan et al., 2004c, 2005; Tanasupawat et al., 2004, 2005; Malimas et al., 2007, 2008). G. asaii is considered to be a later heterotypic synonym of G. cerinus (Katsura et al., 2002; Yamada et al., 1999; Tanaka et al., 1999).

The heterogeneity of strains assigned to $G$. frateurii was recognized by Malimas et al. (2006), based on 16S-23S rRNA gene internal transcribed spacer (ITS) restriction and sequence analyses. In a restriction analysis of the 16S-23S rRNA gene ITS with six restriction endonucleases, the strains were largely divided into two groups, Group III and Group IV. However, Group III was further divided into Group III-1, Group III-2, Group III-3, Group III-4 and Group III-5. In a phylogenetic tree based on 16S-23S rRNA 
gene ITS sequences, the strains constituted three large clusters: (i) a large cluster that included strains of Group III-2, including the type strain of G. frateurii, Group IV and Subgroup III-1a; (ii) a second large cluster that included strains of Group III-3, including the type strain of $G$. thailandicus, and Subgroup III-1b; (iii) a third large cluster that included five strains of Group III-5, Subgroup III-4a and Subgroup III-4b. Phylogenetically, the five strains of the third large cluster were suggested to constitute a new taxon separate from either $G$. frateurii or $G$. thailandicus.

A similar cluster, designated Cluster 1-2, was recognized by Takahashi et al. (2006) in a phylogenetic tree based on 16S-23S rRNA gene ITS sequences. The five strains examined in this paper were included in this cluster and it was suggested that the strains should be classified as representing G. frateurii or a novel species.

In this paper we propose the name Gluconobacter japonicus sp. nov. to accommodate the five strains grouped into Group III-5, Subgroup III-4a and Subgroup III-4b.

The five strains, NBRC $3271^{\mathrm{T}}$ (received as G. frateurii from NBRC), NBRC 3272 (received as G. frateurii) and NBRC 3263 (received as G. cerinus) of Group III-5, NBRC 3260 (received as G. frateurii) of Subgroup III-4a and NBRC 3269 (received as G. cerinus) of Subgroup III-4b were examined genetically, phylogenetically, phenotypically and chemotaxonomically. G. frateurii NBRC $3264^{\mathrm{T}}$, G. thailandicus BCC $14116^{\mathrm{T}}$, G. oxydans NBRC $14819^{\mathrm{T}}$, G. cerinus NBRC $3267^{\mathrm{T}}$, G. albidus NBRC $3250^{\mathrm{T}}$, G. kondonii NBRC $3266^{\mathrm{T}}$ and Acetobacter aceti NBRC $14818^{\mathrm{T}}$ were used as reference strains.

Extraction and isolation of bacterial chromosome DNA were performed by using a modification of the method of Marmur (1961) (Saito \& Miura, 1963; Ezaki et al., 1983). The DNA base composition was determined by using the method of Tamaoka \& Komagata (1984). The DNA G + C contents of strains NBRC $3271^{\mathrm{T}}$, NBRC 3272 , NBRC 3263 , NBRC 3260 and NBRC 3269, respectively, were 56.4, 56.4, $56.4,55.1$ and $55.7 \mathrm{~mol} \%$, with a range of $1.3 \mathrm{~mol} \%$. The data obtained indicated that the five strains are included in a low DNA G $+\mathrm{C}$ content group, phenon A or a sublineage of G. crinus/G. frateurii, along with the type strains of $G$. cerinus, G. frateurii and G. thailandicus (Yamada \& Akita, 1984a; Gosselé et al., 1983; Yamada et al., 1984, 2000; Mason \& Claus, 1989; Tanasupawat et al., 2004).

DNA-DNA hybridization was carried out by using the photobiotin-labelling method with microplate wells, as described by Ezaki et al. (1989) (Yukphan et al., 2004c, d; Malimas et al., 2007). Levels of DNA-DNA hybridization were determined colorimetrically (Verlander, 1992). The colour intensity was measured at $A_{450}$ using a model VersaMax microplate reader (Molecular Devices). When single-stranded and labelled DNA from strain NBRC $3271^{\mathrm{T}}$ was hybridized with DNA from the test strains in $2 \times$ SSC containing $50 \%$ formamide at $49.0{ }^{\circ} \mathrm{C}$ for $15 \mathrm{~h}$, levels of DNA-DNA hybridization of 100, 100, 100, 100, 77, 48, 49,
$29,23,17,16$ and $6 \%$, respectively, were obtained with DNA of the five strains (NBRC $3271^{\mathrm{T}}$, NBRC 3272, NBRC 3263, NBRC 3260 and NBRC 3269) and G. frateurii NBRC $3264^{\mathrm{T}}$, G. thailandicus BCC $14116^{\mathrm{T}}$, G. cerinus NBRC $3267^{\mathrm{T}}$, G. oxydans NBRC $14819^{\mathrm{T}}$, G. albidus NBRC $3250^{\mathrm{T}}$, G. kondonii NBRC $3266^{\mathrm{T}}$ and A. aceti NBRC $14818^{\mathrm{T}}$. In addition, labelled DNA from G. frateurii NBRC $3264^{\mathrm{T}}$ and G. thailandicus BCC $14116^{\mathrm{T}}$ showed DNA-DNA hybridization values of, respectively, 53, 51, 50, 57, 49, 100, 54, 27, $15,15,11$ and $4 \%$ and $49,43,39,44,40,48,100,24,16,15$, 12 and $5 \%$. Among the five strains studied, the calculated DNA-DNA hybridization levels were 70-100\%. Labelled DNA from strains NBRC 3272, NBRC 3263, NBRC 3260 and NBRC 3269 had levels of DNA-DNA hybridization of $34-48,33-51,19-29,19-23,12-19,13-19$ and $4-6 \%$, respectively, to G. frateurii $\mathrm{NBRC} 3264^{\mathrm{T}}$, G. thailandicus BCC $14116^{\mathrm{T}}$, G. cerinus NBRC $3267^{\mathrm{T}}$, G. oxydans NBRC $14819^{\mathrm{T}}$, G. albidus NBRC $3250^{\mathrm{T}}$, G. kondonii NBRC $3266^{\mathrm{T}}$ and A. aceti NBRC $14818^{\mathrm{T}}$. The detailed DNA-DNA hybridization results are available in Supplementary Table S1 (in IJSEM Online). The data obtained indicate that, genetically, the five strains can be separated at the species level from the type strains of the six Gluconobacter reference species used.

Micales et al. (1985) found high levels of DNA-DNA hybridization of 77 and $87 \%$, respectively, to strains IFO $3271^{\mathrm{T}}\left(=\mathrm{NBRC} 3271^{\mathrm{T}}\right)$ and IFO 3272 (=NBRC 3272), when hybridized with labelled DNA from strain IFO $3264^{\mathrm{T}}$ $\left(=G\right.$. frateurii NBRC $\left.3264^{\mathrm{T}}\right)$. However, Mason \& Claus (1989) did not designate the two strains as representing $G$. frateurii. On the other hand, Tanaka et al. (1999) found low levels of DNA-DNA hybridization of 45, 56, 50 and $53 \%$, respectively, for strains IFO $3271^{\mathrm{T}}\left(=\mathrm{NBRC} 3271^{\mathrm{T}}\right)$, IFO 3263 (=NBRC 3263), IFO 3260 (=NBRC 3260) and IFO 3269 (=NBRC 3269) with labelled DNA from the type strain of G. frateurii. Considering the phylogenetic relationships represented previously by Malimas et al. (2006) and Takahashi et al. (2006) and as shown below that the two strains, NBRC $3271^{\mathrm{T}}\left(=\mathrm{IFO} 3271^{\mathrm{T}}\right)$ and NBRC 3272 (IFO 3272), constituted a third large cluster, the low levels of DNA-DNA hybridization of $45-56 \%$ calculated by Tanaka et al. (1999) were reasonable from the phylogenetic point of view.

Phylogenetic analyses based on $16 \mathrm{~S}$ rRNA gene sequences and 16S-23S rRNA gene ITS sequences were performed for the five strains, as described previously (Yukphan et al., 2004b, d; Malimas et al., 2006, 2007). Multiple sequence alignments were made using the program CLUSTAL_X (version 1.81) (Thompson et al., 1997). Sequence gaps and ambiguous bases were excluded. Distance matrices were calculated by using the two-parameter method of Kimura (1980). The neighbour-joining method was used for constructing phylogenetic trees (Saitou \& Nei, 1987). In addition, the maximum-parsimony and the maximumlikelihood methods were used (Felsenstein, 1981, 1983). The robustness of individual branches was estimated by bootstrapping based on 1000 replications (Felsenstein, 


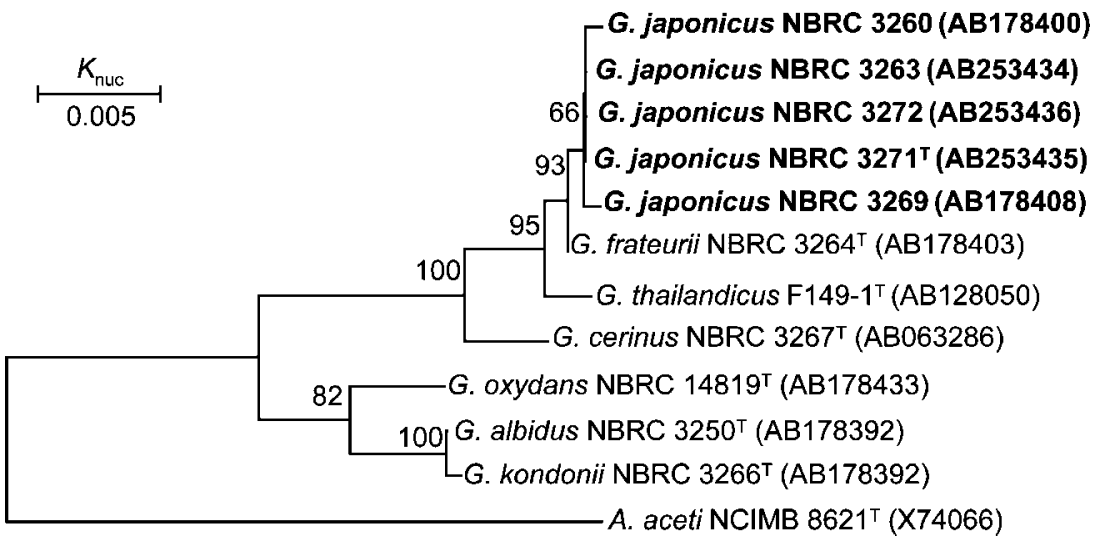

Fig. 1. Phylogenetic relationships of strains NBRC $3271^{\top}$, NBRC 3272, NBRC 3263, NBRC 3260 and NBRC 3269 (G. japonicus sp. nov.). The phylogenetic tree was based on 16S rRNA gene sequences and was constructed by using the neighbour-joining method. The type strain of Acetobacter aceti was used as an outgroup. Numbers at nodes indicate bootstrap percentages derived from 1000 replications. Bar, $0.005 K_{\text {nuc }}$.
1985) with the program MEGA (version 4.0; Tamura et al., 2007). In particular, the program PHYLIP (version 3.6; Felsenstein, 1995) was used to construct a phylogenetic tree using the maximum-likelihood method.

In a phylogenetic tree based on $16 \mathrm{~S}$ rRNA gene sequences of 1428 nt constructed using the neighbour-joining method, the five strains formed a cluster that was separate from the type strains of $G$. frateurii and $G$. thailandicus (Fig. 1) (Takahashi et al., 2006; Malimas et al., 2006). In phylogenetic trees constructed using the maximumparsimony and maximum-likelihood methods, similar clustering was found (data not shown). In a phylogenetic tree based on 16S-23S rRNA gene ITS sequences of $691 \mathrm{nt}$, constructed using the neighbour-joining method, the five strains formed a cluster that was similar to that obtained based upon 16S rRNA gene sequences (data not shown) (Malimas et al., 2006). The data above indicate that the five strains can be separated phylogenetically from the type strains of the six Gluconobacter species studied.

Pairwise 16S rRNA gene sequence similarities of strain NBRC $3271^{\mathrm{T}}$ (for $1430 \mathrm{nt}$ ) were calculated to be 100, 100, 99.9, 99.9, 99.9, 99.7, 99.2, 98.0, 97.9 and 97.9\%, respectively, to strains NBRC 3272, NBRC 3263, NBRC 3260 and NBRC 3269 and the type strains of $G$. frateurii, $G$. thailandicus, G. cerinus, G. oxydans, G. albidus and $G$. kondonii. The pairwise sequence similarities between the five strains were 99.9-100\%. Using the 16S-23S rRNA gene ITS sequences, the calculated pairwise sequence similarities of strain NBRC $3271^{\mathrm{T}}(747 \mathrm{nt})$ were, respectively, 99.9, 99.9, 99.3, 99.7, 97.9, 97.4, 95.8, 83.4, 82.7 and $82.6 \%$. The pairwise sequence similarities between the five strains were $99.3-100 \%$. The calculated pairwise $16 \mathrm{~S}$ rRNA gene sequence similarities of 99.9 and $99.7 \%$, respectively, between strain NBRC $3271^{\mathrm{T}}$ and the type strain of $G$. frateurii and between strain NBRC $3271^{\mathrm{T}}$ and the type strain of $G$. thailandicus were high. However, based on the DNA-DNA hybridization data detailed above, strain NBRC $3271^{\mathrm{T}}$ was separate genetically at the species level.

As the five strains studied could be distinguished from the type strain of either $G$. frateurii or $G$. thailandicus in the low DNA G + C content group by the 16S-23S rRNA gene ITS restriction analysis using TaqI (Malimas et al., 2006), the 16S-23S rRNA gene ITS PCR products of the five strains were prepared and analysed by digestion with MboII, Bsp1286I and BstNI in addition to TaqI (Trček \& Teuber, 2002; Yukphan et al., 2004a, b; Malimas et al., 2006). As shown in Fig. 2(a, b), the five strains could be distinguished from the type strains of $G$. oxydans, $G$. cerinus, G. albidus and $G$. kondonii using MboII and Bsp1286I digestions. In addition, the five strains could be distinguished from the type strains of $G$. frateurii and $G$. thailandicus by TaqI and Bst NI digestions (Fig. 2c, d). The data given above indicate that the five strains can be discriminated from the type strains of the six Gluconobacter species used by using 16S-23S rRNA gene ITS restriction analysis with MboII, Bsp1286I, TaqI and BstNI.

The morphological, physiological and biochemical characteristics of the five strains were examined as described previously (Yamada et al., 1976, 1999; Katsura et al., 2002) and by Asai et al. (1964), Gosselé et al. (1983) and Mason \& Claus (1989). The ubiquinone system was determined by using the method of Yamada et al. (1969). The phenotypic and chemotaxonomic characteristics determined are given in the species description.

The five strains could be discriminated from the type strains of G. oxydans, G. albidus and G. kondonii, which are grouped in the high DNA G $+C$ content group, by growth in the presence of L-arabitol (weakly positive in strains NBRC $3271^{\mathrm{T}}$, NBRC 3272 and NBRC 3263) and mesoribitol, as well as by the ability to grow without nicotinic acid (Table 1). The five strains weakly produced dihydroxyacetone from glycerol, different from the type strains of $G$. frateurii, G. thailandicus, G. cerinus, G. oxydans, G. albidus and G. kondonii. The five strains produced acid from mesoerythritol [different from the type strains of $G$. frateurii (weakly positive) and G. albidus (weakly positive)] and from raffinose [different from the type strains of $G$. thailandicus (weakly positive), G. cerinus (weakly positive) and $G$. oxydans (weakly positive)], but not from maltose (weakly positive in strains NBRC 3260 and NBRC 3269), different 
(a)

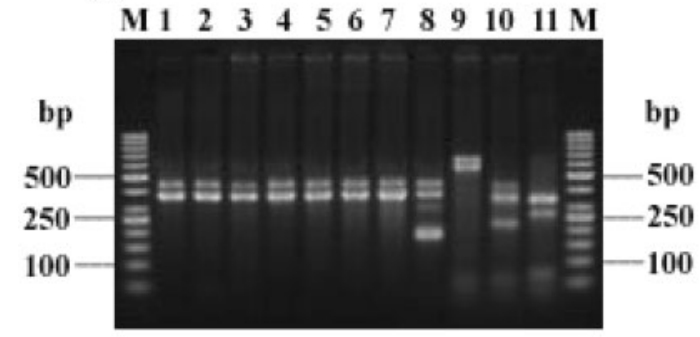

(c)

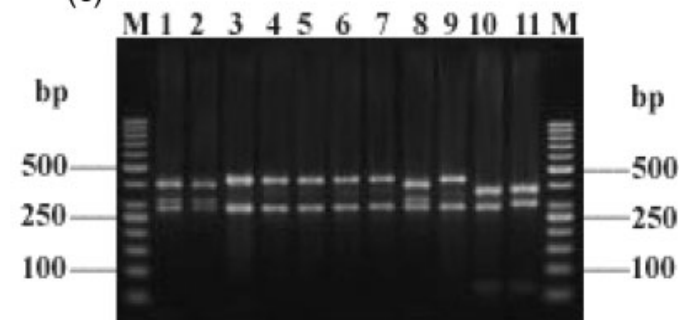

(b)

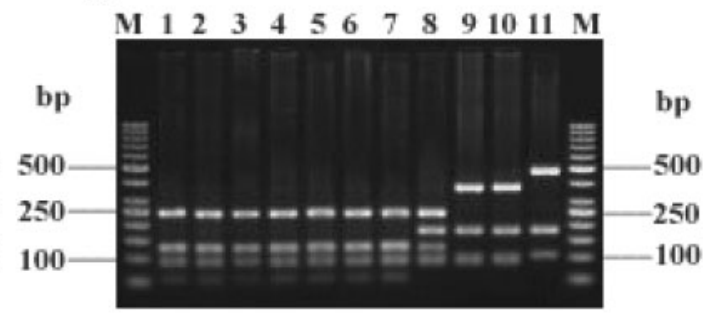

(d)

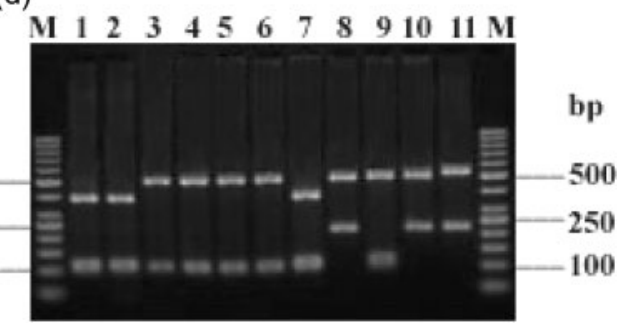

Fig. 2. Digestion of $16 \mathrm{~S}-23 \mathrm{~S}$ rRNA gene ITS of strains NBRC $3271^{\top}$, NBRC 3272 , NBRC 3263 , NBRC 3260 and NBRC 3269 (G. japonicus sp. nov.) with restriction endonucleases. The restriction patterns were obtained by digestion of 16S-23S rRNA gene ITS PCR products with Mboll (a), Bsp1286I (b), Taql (c) and BstNI (d). For estimation of the resulting restriction fragments, 50 bp DNA markers were used in agarose gel electrophoresis. Lanes: 1 , G. frateurii NBRC $3264^{\top} ; 2, G$. thailandicus BCC $14116^{\top} ; 3$, strain NBRC $3271^{\top} ; 4$, strain NBRC 3272; 5 , strain NBRC $3263 ; 6$, strain NBRC 3260; 7 , strain NBRC $3269 ; 8$, G. cerinus NBRC $3267^{\top} ; 9$, G. oxydans NBRC $14819^{\top} ; 10$, G. albidus NBRC $3250^{\top} ; 11$, G. kondonii NBRC $3266^{\top}$; M, 50 bp DNA marker.

from the type strains of $G$. frateurii (weakly positive) and $G$. oxydans. The five strains grew on meso-erythritol, different from the type strains of G. frateurii, G. thailandicus (weakly positive), G. oxydans (weakly positive) and G. albidus. In growth on pentitol, the five strains grew on D-arabitol (different from the type strains of G. oxydans and G. albidus) and on meso-ribitol [different from the type strains of $G$. thailandicus (weakly positive), G. cerinus (weakly positive), G. oxydans, G. albidus and G. kondonii].

The five strains could be discriminated from the type strains of G. oxydans, G. albidus, G. kondonii and G. cerinus by $16 \mathrm{~S}-23 \mathrm{~S}$ rRNA gene ITS restriction analysis with MboII and Bsp1286I (Table 1) (Yukphan et al. 2004a, b). In addition, the five strains represented a different kind of restriction pattern especially from those of the type strains of $G$. frateurii and G. thailandicus by digestion with TaqI (Malimas et al., 2006).

As described above, the five strains studied could be distinguished genetically, phylogenetically, morphologically, physiologically, biochemically and chemotaxonomically from the type strains of G. oxydans, G. albidus, G. kondonii, G. cerinus, G. frateurii and G. thailandicus (Table 1). A novel species is therefore proposed to accommodate the five strains grouped into the low DNA G $+\mathrm{C}$ content group, phenon A or the sublineage of G. cerinus/G. frateurii, with the name Gluconobacter japonicus sp. nov.

\section{Description of Gluconobacter japonicus sp. nov.}

Gluconobacter japonicus (ja.po.ni'cus. N.L. masc. adj. japonicus of Japan, where the type strain was isolated).

Cells are Gram-negative rods, measuring 0.8-1.0 $\times 1.0-$ $2.0 \mu \mathrm{m}$. Variable results are obtained for motility and the presence of polar flagella. Grows at $\mathrm{pH} 3.0$ and $35{ }^{\circ} \mathrm{C}$. Maximum growth occurs at $\mathrm{pH} 5.5$ and $25^{\circ} \mathrm{C}$. Does not oxidize acetate or lactate. Grows on mannitol agar but not on glutamate agar. Produces dihydroxyacetone (weakly positive) from glycerol and 2-keto-D-gluconate and 5-ketoD-gluconate from D-glucose, but not 2,5-diketo-D-gluconate or a water-soluble brown pigment from D-glucose. Acid is produced from D-glucose, D-mannose, D-galactose, D-xylose, D-arabinose, L-arabinose, L-rhamnose (weakly positive), D-fructose, L-sorbose, D-mannitol, D-sorbitol, meso-erythritol, glycerol, melibiose, sucrose, raffinose and ethanol. Acid is not produced from dulcitol or lactose. Variable results are obtained for acid production from maltose. Grows on D-glucose, D-fructose, D-mannitol, Dsorbitol, meso-erythritol and glycerol. Variable results are obtained for growth on D-arabinose, L-arabinose, Lrhamnose, L-sorbose, sucrose and raffinose. Does not grow on D-mannose, D-galactose, D-xylose, dulcitol, maltose, melibiose, lactose or ethanol. Grows on pentitol with Darabitol and meso-ribitol. Variable results are obtained for growth on pentitol with L-arabitol. Does not require 
Table 1. Characteristics that differentiate strains NBRC $3271^{\top}$, NBRC 3272 , NBRC 3263 , NBRC 3260 and NBRC 3269 (Gluconobacter japonicus sp. nov.) from the type strains of the six Gluconobacter species studied

Strains: 1, NBRC $3271^{\mathrm{T}}$; 2, NBRC 3272; 3, NBRC 3263; 4, NBRC 3260; 5, NBRC 3269; 6, G. frateurii NBRC 3264 ${ }^{\mathrm{T}}$; 7, G. thailandicus BCC $14116^{\mathrm{T}}$; 8 , G. cerinus NBRC $3267^{\mathrm{T}}$; 9, G. oxydans NBRC $14819^{\mathrm{T}}$; 10, G. albidus NBRC $3250^{\mathrm{T}}$; 11, G. kondonii NBRC $3266^{\mathrm{T}}$. +, Positive; -, negative; w, weakly positive; ND, not determined; Gf, G. frateurii; Gc, G. cerinus; Go, G. oxydans; Ga, G. albidus; Gk, G. kondonii.

\begin{tabular}{|c|c|c|c|c|c|c|c|c|c|c|c|}
\hline Characteristic & 1 & 2 & 3 & 4 & 5 & 6 & 7 & 8 & 9 & 10 & 11 \\
\hline Production of dihydroxyacetone & $\mathrm{W}$ & W & $\mathrm{W}$ & $\mathrm{W}$ & $\mathrm{W}$ & + & + & + & + & + & + \\
\hline \multicolumn{12}{|l|}{ Acid production from: } \\
\hline meso-Erythritol & + & + & + & + & + & $\mathrm{W}$ & + & + & + & $\mathrm{W}$ & + \\
\hline Maltose & - & - & - & $\mathrm{W}$ & $\mathrm{w}$ & $\mathrm{w}$ & - & - & + & - & - \\
\hline Raffinose & + & + & + & + & + & + & $\mathrm{W}$ & $\mathrm{W}$ & $\mathrm{W}$ & + & + \\
\hline \multicolumn{12}{|l|}{ Growth on: } \\
\hline meso-Erythritol & + & + & + & + & + & - & $\mathrm{w}$ & + & $\mathrm{W}$ & - & + \\
\hline D-Arabitol & + & + & + & + & + & + & + & + & - & - & + \\
\hline L-Arabitol & $\mathrm{W}$ & $\mathrm{W}$ & $\mathrm{W}$ & + & + & + & $\mathrm{W}$ & - & - & - & - \\
\hline meso-Ribitol & + & + & + & + & + & + & $\mathrm{W}$ & $\mathrm{w}$ & - & - & - \\
\hline Growth without nicotinic acid & + & + & + & + & + & + & + & + & - & - & - \\
\hline \multicolumn{12}{|l|}{ Restriction pattern with $^{\star}$} \\
\hline MboII & Gf & Gf & $G f$ & Gf & Gf & Gf & Gf & $G c$ & Go & $G a$ & Gk \\
\hline Bsp1286I & Gf & Gf & $G f$ & Gf & Gf & Gf & Gf & $G c$ & Go & Go & Gk \\
\hline TaqI & $d$ & $d$ & $d$ & $d$ & $d$ & $c$ & $c$ & ND & ND & ND & ND \\
\hline Bst $\mathrm{NI}$ & $i$ & $i$ & $i$ & $i$ & $h$ & $h$ & $h$ & ND & ND & ND & ND \\
\hline DNA G $+C$ content $(\mathrm{mol} \%)$ & 56.4 & 56.4 & 56.4 & 55.1 & 55.7 & $55.1 \dagger$ & $55.8 \ddagger$ & $55.9 \dagger$ & $60.3 \dagger$ & $60.0 \dagger$ & $59.8 \$$ \\
\hline
\end{tabular}

${ }^{\star}$ For details, see Malimas et al. (2006) and Yukphan et al. (2004a, b).

$\dagger$ From Yukphan et al. (2004c).

$\ddagger$ From Tanasupawat et al. (2004).

§From Malimas et al. (2007).

nicotinic acid for growth. Restriction analysis of the 16S$23 S$ rRNA gene ITS represents the $G f$ type, $d$ type and $i$ or $h$ type of restriction patterns by digestion, respectively, with MboII, Bsp1286I, TaqI and BstNI. Major ubiquinone is Q10. DNA G $+\mathrm{C}$ contents are $55.1-56.4 \mathrm{~mol} \%$.

The type strain, NBRC $3271^{\mathrm{T}}\left(=\right.$ BCC $14458^{\mathrm{T}}=$ strain $7^{\mathrm{T}}$, K. Kondo), was isolated from fruit of Myrica rubra, Chinese bayberry, and has a DNA $\mathrm{G}+\mathrm{C}$ content of $56.4 \mathrm{~mol} \%$ and is motile by means of polar flagella.

\section{Acknowledgements}

This study was supported in part by the Biodiversity Research and Training Program, Bangkok, Thailand.

\section{References}

Asai, T. (1935). A taxonomic study and proposal of a new classification method of the acetic acid bacteria and allied oxidative bacteria that exist in fruit (continued). J Agric Chem Soc Jpn 11, 674-708 (in Japanese).

Asai, T., lizuka, H. \& Komagata, K. (1964). The flagellation and taxonomy of genera Gluconobacter and Acetobacter with reference to the existence of intermediate strains. J Gen Appl Microbiol 10, 95-126.

De Ley, J. (1961). Comparative carbohydrate metabolism and a proposal for a phylogenetic relationship of the acetic acid bacteria. J Gen Microbiol 24, 31-50.
Ezaki, T., Yamamoto, N., Ninomiya, K., Suzuki, S. \& Yabuuchi, E. (1983). Transfer of Peptococcus indolicus, Peptococcus asaccharolyticus, Peptococcus prevotii, and Peptococcus magnus to the genus Peptostreptococcus and proposal of Peptostreptococcus tetradius sp. nov. Int J Syst Bacteriol 33, 683-698.

Ezaki, T., Hashimoto, Y. \& Yabuuchi, E. (1989). Fluorometric deoxyribonucleic acid-deoxyribonucleic acid hybridization in microdilution wells as an alternative to membrane filter hybridization in which radioisotopes are used to determine genetic relatedness among bacterial strains. Int J Syst Bacteriol 39, 224-229.

Felsenstein, J. (1981). Evolutionary trees from DNA sequences: a maximum likelihood approach. J Mol Evol 17, 368-376.

Felsenstein, J. (1983). Parsimony in systematics: biological and statistical issues. Annu Rev Ecol Syst 14, 313-333.

Felsenstein, J. (1985). Confidence limits on phylogenies: an approach using the bootstrap. Evolution 39, 783-791.

Felsenstein, J. (1995). PHYLIP (phylogeny inference package) version 3.6. Distributed by the author. Department of Genome Sciences, University of Washington, Seattle, USA.

Gosselé, F., Swings, J., Kersters, K. \& De Ley, J. (1983). Numerical analysis of phenotypic features and protein gel electropherograms of Gluconobacter Asai 1935 emend. mut. char. Asai, Iizuka and Komagata 1964. Int J Syst Bacteriol 33, 65-81.

Huong, V. T. L., Malimas, T., Yukphan, P., Potacharoen, W., Tanasupawat, S., Loan, L. T. T., Tanticharoen, M. \& Yamada, Y. (2007). Identification of Thai isolates assigned to the genus Gluconobacter based on 16S-23S rDNA ITS restriction analysis. J Gen Appl Microbiol 53, 133-142. 
Katsura, K., Yamada, Y., Uchimura, T. \& Komagata, K. (2002). Gluconobacter asaii Mason and Claus 1989 is a junior subjective synonym of Gluconobacter cerinus Yamada and Akita 1984. Int J Syst Evol Microbiol 52, 1635-1640.

Kimura, M. (1980). A simple method for estimating evolutionary rates of base substitutions through comparative studies of nucleotide sequences. J Mol Evol 16, 111-120.

Malimas, T., Yukphan, P., Takahashi, M., Potacharoen, W., Tanasupawat, S., Nakagawa, Y., Tanticharoen, M. \& Yamada, Y. (2006). Heterogeneity of strains assigned to Gluconobacter frateurii Mason and Claus 1989 based on restriction analysis of 16S-23S rDNA internal transcribed spacer regions. Biosci Biotechnol Biochem 70, 684690.

Malimas, T., Yukphan, P., Takahashi, M., Kaneyasu, M., Potacharoen, W., Tanasupawat, S., Nakagawa, Y., Tanticharoen, M. \& Yamada, Y. (2007). Gluconobacter kondonii sp. nov., an acetic acid bacterium in the $\alpha$-Proteobacteria. J Gen Appl Microbiol 53, 301-307.

Malimas, T., Yukphan, P., Takahashi, M., Kaneyasu, M., Potacharoen, W., Tanasupawat, S., Nakagawa, Y., Tanticharoen, M. \& Yamada, Y. (2008). Gluconobacter kondonii Malimas et al. 2008. In List of New Names and New Combinations Previously Effectively, but not Validly, Published, Validation List no. 120. Int J Syst Evol Microbiol 58, 529-530.

Marmur, J. (1961). A procedure for isolation of deoxyribonucleic acid from microorganisms. J Mol Biol 3, 208-218.

Mason, L. M. \& Claus, G. W. (1989). Phenotypic characteristics correlated with deoxyribonucleic acid sequence similarities for three species of Gluconobacter: G. oxydans (Henneberg 1897) De Ley 1961, G. frateurii sp. nov. and G. asaii sp. nov. Int J Syst Bacteriol 39, 174-184.

Micales, B. K., Johnson, J. L. \& Claus, G. W. (1985). Deoxyribonucleic acid homologies among organisms in the genus Gluconobacter. Int $J$ Syst Bacteriol 35, 79-85.

Saito, H. \& Miura, K. (1963). Preparation of transforming deoxyribonucleic acid by phenol treatment. Biochim Biophys Acta 72, 619-629.

Saitou, N. \& Nei, M. (1987). The neighbor-joining method: a new method for reconstructing phylogenetic trees. Mol Biol Evol 4, 406-425.

Skerman, V. B. D., McGowan, V. \& Sneath, P. H. A. (editors) (1980). Approved lists of bacterial names. Int J Syst Bacteriol 30, 225-420.

Takahashi, M., Yukphan, P., Yamada, Y., Suzuki, K., Sakane, T. \& Nakagawa, Y. (2006). Intrageneric structure of the genus Gluconobacter analyzed by the 16S rRNA gene and 16S-23S rRNA gene internal transcribed spacer sequences. J Gen Appl Microbiol 52, 187-193.

Tamaoka, J. \& Komagata, K. (1984). Determination of DNA base composition by reversed-phase high-performance liquid chromatography. FEMS Microbiol Lett 25, 125-128.

Tamura, K., Dudley, J., Nei, M. \& Kumar, S. (2007). MEGA4: molecular evolutionary genetics analysis (MEGA) software version 4.0. Mol Biol Evol 24, 1596-1599.

Tanaka, M., Murakami, S., Shinke, R. \& Aoki, K. (1999). Reclassification of the strains with low G+C contents of DNA belonging to the genus Gluconobacter Asai 1935 (Acetobacteraceae). Biosci Biotechnol Biochem 63, 989-992.

Tanasupawat, S., Thawai, C., Yukphan, P., Moonmangmee, D., Itoh, T., Adachi, O. \& Yamada, Y. (2004). Gluconobacter thailandicus sp. nov., an acetic acid bacterium in the $\alpha$-Proteobacteria. J Gen Appl Microbiol 50, 159-167.

Tanasupawat, S., Thawai, C., Yukphan, P., Moonmangmee, D., Itoh, T., Adachi, O. \& Yamada, Y. (2005). Gluconobacter thailandicus Tanasupawat et al. 2005. In Validation of the Publication of New Names and New Combinations Previously Effectively Published Outside the IJSEM, List no. 103. Int J Syst Evol Microbiol 55, 983-985.
Thompson, J. D., Gibson, T. J., Plewniak, F., Jeanmougin, F. \& Higgins, D. G. (1997). The CLUSTAL_X windows interface: flexible strategies for multiple sequence alignment aided by quality analysis tools. Nucleic Acids Res 25, 4876-4882.

Trček, J. \& Teuber, M. (2002). Genetic and restriction analysis of the 16S-23S rDNA internal transcribed spacer regions of the acetic acid bacteria. FEMS Microbiol Lett 208, 69-75.

Verlander, C. P. (1992). Detection of horseradish peroxidase by colorimetry. In Nonisotopic DNA Probe Techniques, pp. 185-201. Edited by L. J. Kricka. New York: Academic Press.

Yamada, Y. \& Akita, M. (1984a). An electrophoretic comparison of enzymes in strains of Gluconobacter species. J Gen Appl Microbiol 30, 115-126.

Yamada, Y. \& Akita, M. (1984b). Gluconobacter cerinus. In Validation of the Publication of New Names and New Combinations Previously Effectively Published Outside the IJSB, List no. 16. Int J Syst Bacteriol 34, 503-504.

Yamada, Y., Aida, K. \& Uemura, T. (1969). Enzymatic studies on the oxidation of sugar and sugar alcohol. V. Ubiquinone of acetic acid bacteria and its relation to classification of Gluconobacter and Acetobacter, especially of the so-called intermediate strains. J Gen Appl Microbiol 15, 186-196.

Yamada, Y., Okada, Y. \& Kondo, K. (1976). Isolation and characterization of "polarly flagellated intermediate strains" in acetic acid bacteria. J Gen Appl Microbiol 22, 237-245.

Yamada, Y., Itakura, N., Yamashita, M. \& Tahara, Y. (1984). Deoxyribonucleic acid homologies in strains of Gluconobacter species. J Ferment Technol 62, 595-600.

Yamada, Y., Hosono, R., Lisdiyanti, P., Widyastuti, Y., Saono, S., Uchimura, T. \& Komagata, K. (1999). Identification of acetic acid bacteria isolated from Indonesian sources, especially of isolates classified in the genus Gluconobacter. J Gen Appl Microbiol 45, 23-28.

Yamada, Y., Katsura, K., Kawasaki, H., Widyastuti, Y., Saono, S., Seki, T., Uchimura, T. \& Komagata, K. (2000). Asaia bogorensis gen. nov., sp. nov., an unusual acetic acid bacterium in the $\alpha$ Proteobacteria. Int J Syst Evol Microbiol 50, 823-829.

Yukphan, P., Potacharoen, W., Nakagawa, Y., Tanticharoen, M. \& Yamada, Y. (2004a). Identification of strains assigned to the genus Gluconobacter Asai 1935 based on the sequence and the restriction analyses of the 16S-23S rDNA internal transcribed spacer regions. J Gen Appl Microbiol 50, 9-15.

Yukphan, P., Malimas, T., Takahashi, M., Potacharoen, W., Busabun, T., Tanasupawat, S., Nakagawa, Y., Tanticharoen, M. \& Yamada, Y. (2004b). Re-identification of Gluconobacter strains based on the restriction analysis of the $16 \mathrm{~S}-23 \mathrm{~S}$ rDNA internal transcribed spacer regions. J Gen Appl Microbiol 50, 189-195.

Yukphan, P., Takahashi, M., Potacharoen, W., Tanasupawat, S., Nakagawa, Y., Tanticharoen, M. \& Yamada, Y. (2004c). Gluconobacter albidus (ex Kondo and Ameyama 1958) sp. nov., nom. rev., an acetic acid bacterium in the $\alpha$-Proteobacteria. J Gen Appl Microbiol 50, 235-242.

Yukphan, P., Potacharoen, W., Tanasupawat, S., Tanticharoen, M. \& Yamada, Y. (2004d). Asaia krungthepensis sp. nov., an acetic acid bacterium in the $\alpha$-Proteobacteria. Int J Syst Evol Microbiol 54, 313316.

Yukphan, P., Takahashi, M., Potacharoen, W., Tanasupawat, S., Nakagawa, Y., Tanticharoen, M. \& Yamada, Y. (2005). Gluconobacter albidus (ex Kondo and Ameyama 1958) Yukphan et al. 2005. In Validation of the Publication of New Names and New Combinations Previously Effectively Published Outside the IJSEM, List no. 103. Int J Syst Evol Microbiol 55, 983-985. 